\title{
MODELING AND ANALYSIS OF CONTROL CIRCUIT FOR BIOGAS ELECTRIFICATION TECHNOLOGY
}

\author{
Sharmin Sobhan ${ }^{1}$, Tanvir Ahmad ${ }^{2}$ \\ ${ }^{1}$ Lecturer, Dept of EEE, Ahsanullah University of Science and Technology, Dhaka, Bangladesh. \\ ${ }^{2}$ Lecturer, Dept of EEE, Ahsanullah University of Science and Technology, Dhaka, Bangladesh
}

\begin{abstract}
For sustainable development, balanced energy portfolio is required that is suited to the economic, social, environment and resource conditions of a specific region or the whole world. Energy resources are fossil fuels, nuclear sources and renewable resources. Conventional energy resources are limited as well as they are subjected to pollution due to combustion and chemical processes. Biogas, one of the renewable resources, is produced from various biomass sources through biochemical process. Electricity and heat can be produced from it with minor clean up. Bangladesh has a plenty biomass resources which can play an important role for country's development. For electricity generation, control circuit is needed to have desired and controlled output.

This paper addresses on biogas, its biochemical processes and electricity generation process from biogas. It also shows the potential and prospects of biogas electrification technology for rural Bangladesh. Paper explore mathematical model and explain actions of control circuits those are connected to the generator though simulation.
\end{abstract}

Key Words: Renewable energy; Biogas; Biochemical process; Electricity generation; Potentials; Mathematical model; Control circuit; DC converter.

\section{INTRODUCTION}

Natural Gas is used as main fuel for electricity generation in Bangladesh [1]. Alarming issue is that, the country's gas reserves stand at 14.16 trillion cubic feet (tcf) as of June 2015 and 12.96 bcf gases was extracted until May, 2015. If the current rate of extraction remains unchanged, the reserve would last until 2031[2].

Table -1: Installed capacity of BPDB power plants on September 2015[3]

\begin{tabular}{|l|l|l|}
\hline Fuel Type & Capacity(Unit) & Total $(\%)$ \\
\hline Coal & $250.00 \mathrm{MW}$ & $2.14 \%$ \\
\hline Gas & $7280.00 \mathrm{MW}$ & $62.31 \%$ \\
\hline HFO & $2507.00 \mathrm{MW}$ & $21.46 \%$ \\
\hline HSD & $916.00 \mathrm{MW}$ & $7.84 \%$ \\
\hline Hydro & $230.00 \mathrm{MW}$ & $1.97 \%$ \\
\hline Imported & $500.00 \mathrm{MW}$ & $4.28 \%$ \\
\hline Total & $11683.00 \mathrm{MW}$ & $100 \%$ \\
\hline
\end{tabular}

On the top of that country provides electricity to only $74 \%$ of its population and maximum people in rural areas are living, without electricity. Under this circumstance biogas based technology could be found effective for country's development [4].

Biogas technology, the generation of a combustible gas from anaerobic digestion, is a well-known technology. But producing electricity from biogas is still relatively rare in most developing countries.
Table -2: Bangladesh's power sector at a glance (June 2015) [5]

\begin{tabular}{|ll|}
\hline Generation Capacity & $: 11,534 \mathrm{MW}^{*}$ (June, 2015) \\
\hline $\begin{array}{l}\text { Highest Generation } \\
\text { 2015) }\end{array}$ & $: 177 \mathrm{MW} \mathrm{(13} \mathrm{August,}$ \\
\hline Total Consumers & $: 17.5$ Million (June, 2015) \\
\hline Transmission Line & $: 9,695 \mathrm{ckt} \mathrm{km}$ \\
\hline Distribution Line & $: 3,26,000 \mathrm{~km}$ \\
\hline Distribution Loss & $: 11.36 \%$ \\
\hline Per Capita Generation & $: 371 \mathrm{KWh}$ \\
\hline Access to Electricity & $: 74 \%$ \\
\hline
\end{tabular}

This document discusses electricity generation process, its potential in Bangladesh and mathematical model of the generating unit. Main objective of the study is to analysis control circuit performances.

\section{RENEWABLE ENERGY}

Renewable energy comes from natural resources such as sunlight, wind, rain, tides, and geothermal heat, which are renewable (naturally replenished).

- Mainstream forms of renewable energy:

* Wind power

* Hydro power

* Solar energy

* Biomass

* Biogas

* Geothermal energy

- Importance of renewable energy: 


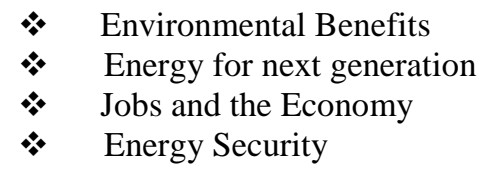

\section{BIOGAS}

Biogas is a flammable gas that accrues from the fermentation of biomass in biogas plants. Biogas can be produced utilizing anaerobic digesters. These plants can be fed with energy crops such as maize silage or biodegradable wastes including sewage sludge and food waste [6]. During the process, an air-tight tank transforms waste into methane that can be used for heating, electricity, and many other operations that use any variation of an internal combustion engine.

\subsection{Biogas Composition}

Table -3: Biogas Composition

\begin{tabular}{|l|l|l|}
\hline \multicolumn{3}{|c|}{ Typical Composition of Biogas } \\
\hline Compound & Chemical Properties & $\%$ \\
\hline Methane & $\mathrm{CH}_{4}$ & $50-75$ \\
\hline $\begin{array}{l}\text { Carbon } \\
\text { dioxide }\end{array}$ & $\mathrm{CO}_{2}$ & $25-50$ \\
\hline Nitrogen & $\mathrm{N}_{2}$ & $0-10$ \\
\hline Hydrogen & $\mathrm{H}_{2}$ & $0-1$ \\
\hline $\begin{array}{l}\text { Hydrogen } \\
\text { sulphide }\end{array}$ & $\mathrm{H}_{2} \mathrm{~S}$ & $0-3$ \\
\hline Oxygen & $\mathrm{O}_{2}$ & $0-0$ \\
\hline
\end{tabular}

Depending on temperature, there are two key processes [7]:

* Mesophilic digestion (between $20^{\circ} \mathrm{C}$ and $40^{\circ} \mathrm{C}$ ).

* Thermophilic digestion(above $40^{\circ} \mathrm{C}$ )

\subsection{Biological and Chemical Stages}

The overall process can be described by the chemical reaction, where organic material such as glucose is biochemically digested into carbon dioxide $\left(\mathrm{CO}_{2}\right)$ and methane $\left(\mathrm{CH}_{4}\right)$ by the anaerobic microorganisms.

$$
\mathrm{C}_{6} \mathrm{H}_{12} \mathrm{O}_{6} \rightarrow 3 \mathrm{CO}_{2}+3 \mathrm{CH}_{4}
$$

Anaerobic decomposition of organic compounds is conducted in close cooperation of specialized bacteria of different types, including mostly hydrolyzing, digestive, acetogenic, homoacetogenic, sulfate-reducing (VI) and methanogenic bacteria.

There are four key biological and chemical stages of anaerobic digestion [7]:

$$
\begin{array}{ll}
* & \text { Hydrolysis } \\
\text { * Acidogenesis } \\
\text { * Acetogenesis } \\
\text { Methanogenesis }
\end{array}
$$

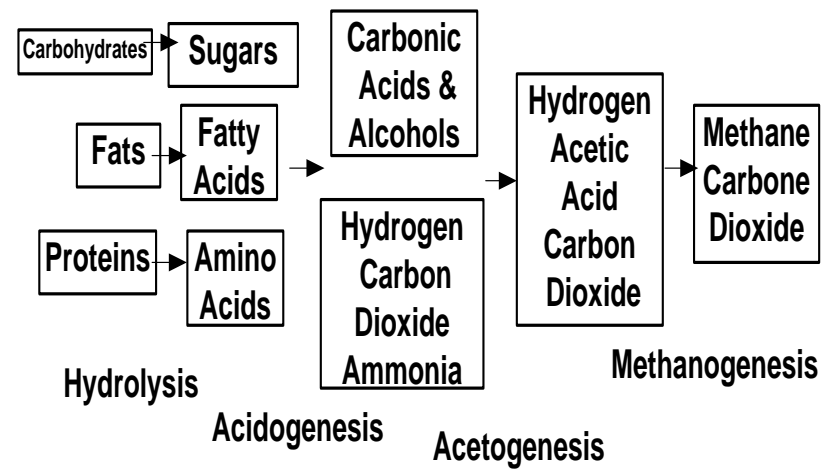

Fig-1: Biological and chemical stages of anaerobic digestion

\subsection{Energy Content}

Table -4: Energy Contents in Different Substrates [8]

\begin{tabular}{|l|l|}
\hline Substrates & K Wh/Ton \\
\hline Cow dung & 140 \\
\hline Manure from pigs & 180 \\
\hline Manure from poultry & 450 \\
\hline Gras & 810 \\
\hline Waste from fruits and vegetables & 950 \\
\hline Household food waste & 1.300 \\
\hline Food waste from restaurants & 1.300 \\
\hline Waste from slaughterhouses & 2.000 \\
\hline Pure carbohydrates/sugar & 3.900 \\
\hline Proteins & 4.900 \\
\hline Fat & 8.500 \\
\hline
\end{tabular}

\subsection{Electricity Generation Process From Biogas}

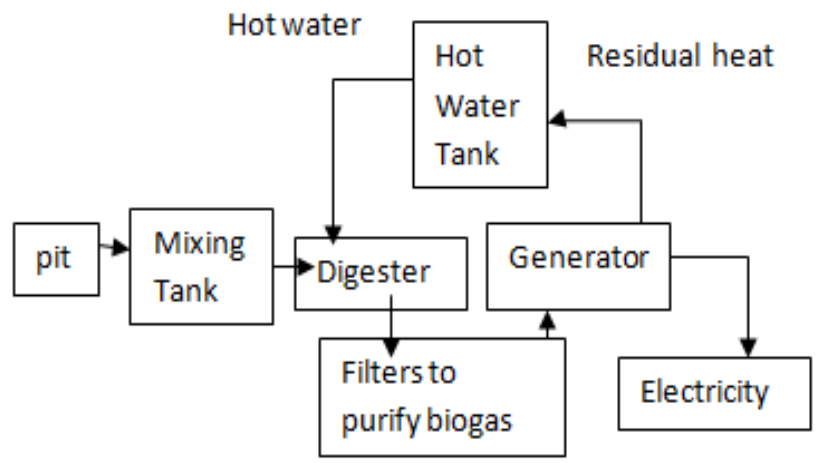

Fig.-2: Process diagram of electricity generation from biogas 


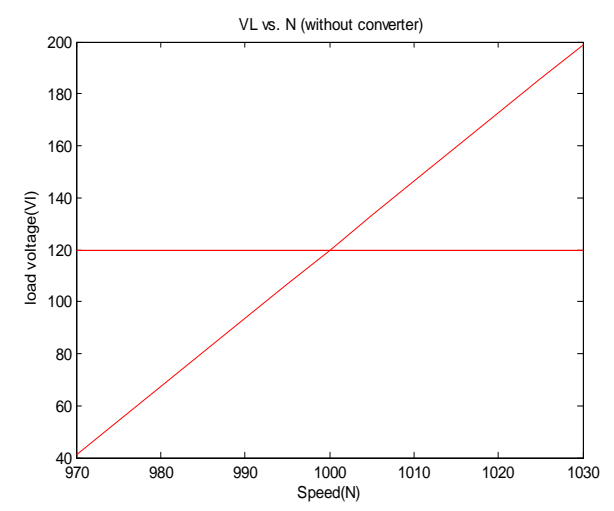

Fig-5: $V_{L}$ vs. $N$ curve

\section{CONTROL CIRCUIT ANALYSIS}

The normal speed of an electric power generator is maintained by a control system that balances the demand on the generator and the steam supplied to the generator, in reference to the power system frequency.

In the event when the load voltage fluctuated from the desired value, the control system is designed to recover the load voltage simultaneously to get the desired controlled output from the generator.

\subsection{Buck Converter}

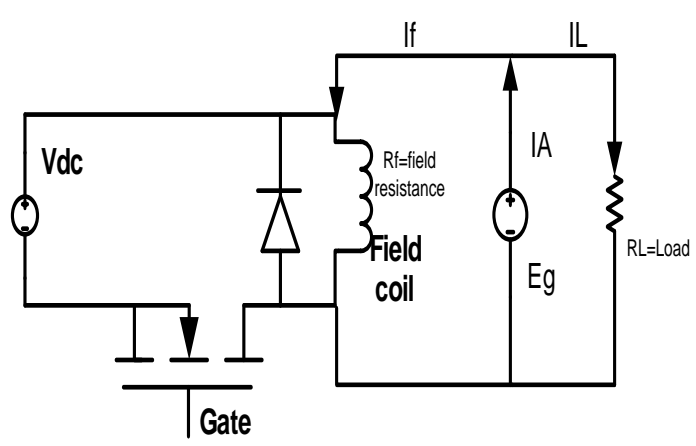

Fig-6: Generator along with buck converter

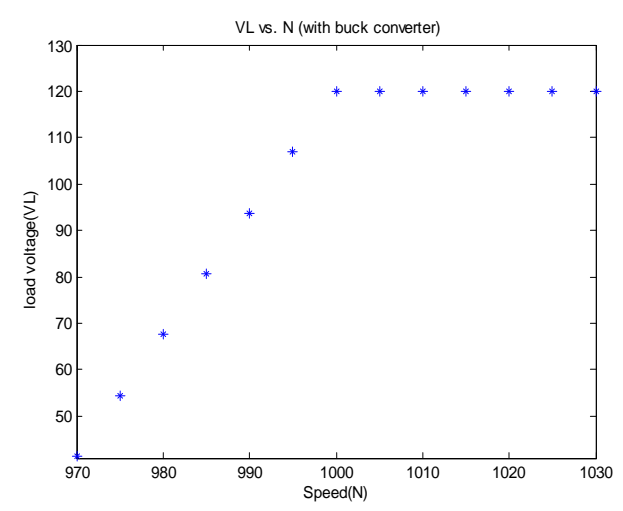

Fig-7: $\mathrm{V}_{\mathrm{L}}$ vs. $\mathrm{N}$ Curve (Buck)

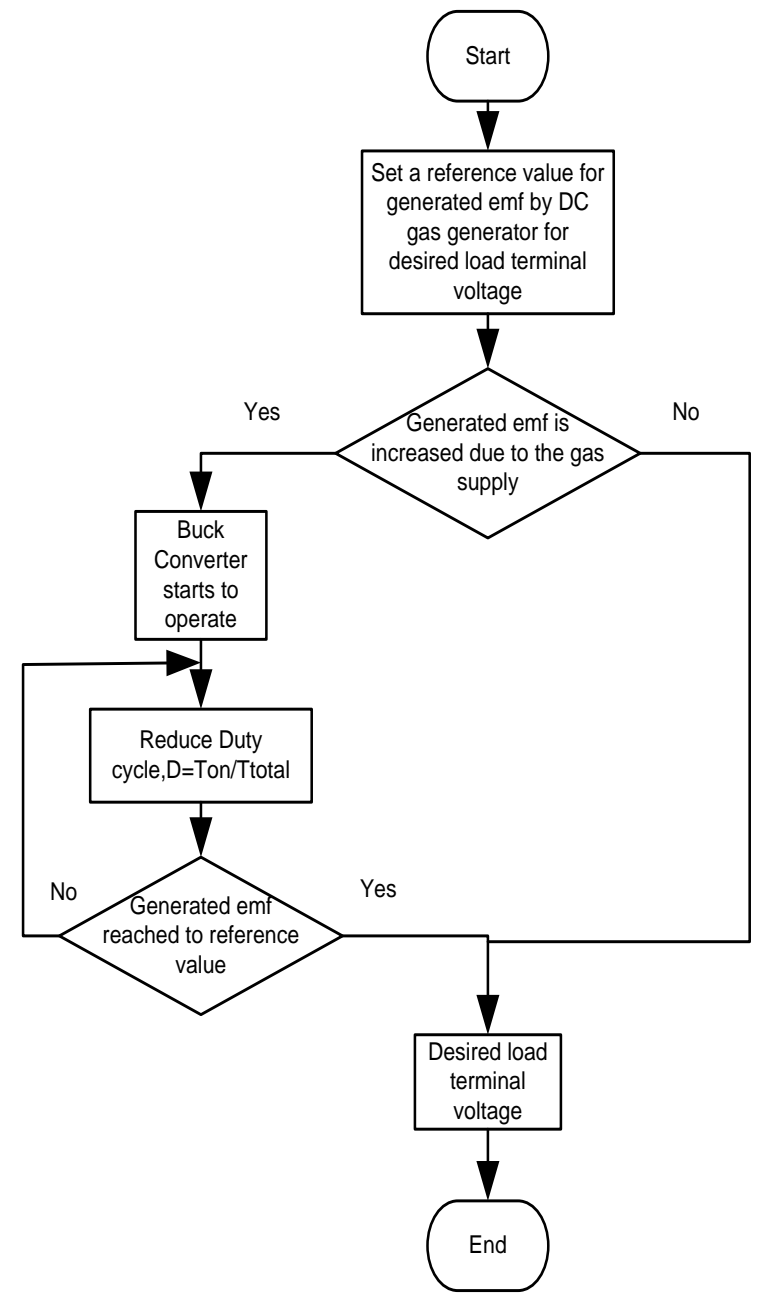

Fig-8: Algorithm for Buck controlled circuit

If the load voltage is increased from desired value, this control circuit will reduced it by changing duty cycle to protect load from over voltages.

Duty cycle $=\frac{\text { Voutput }}{\text { Vinput }}$

\subsection{Buck-Boost Converter}

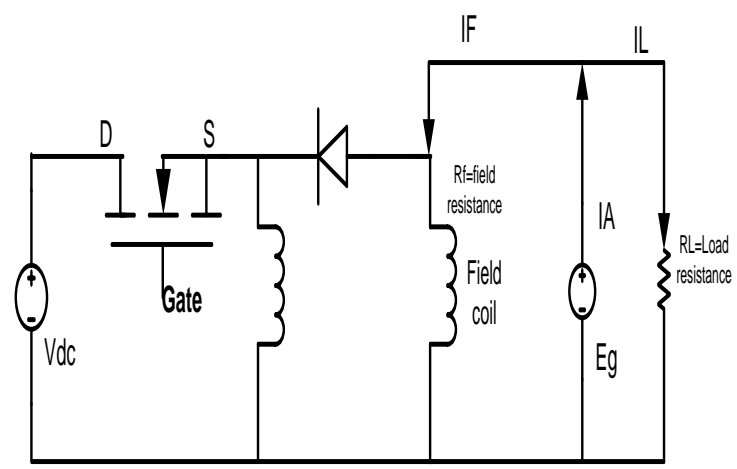

Fig-9: Generator along with Buck-Boost converter 


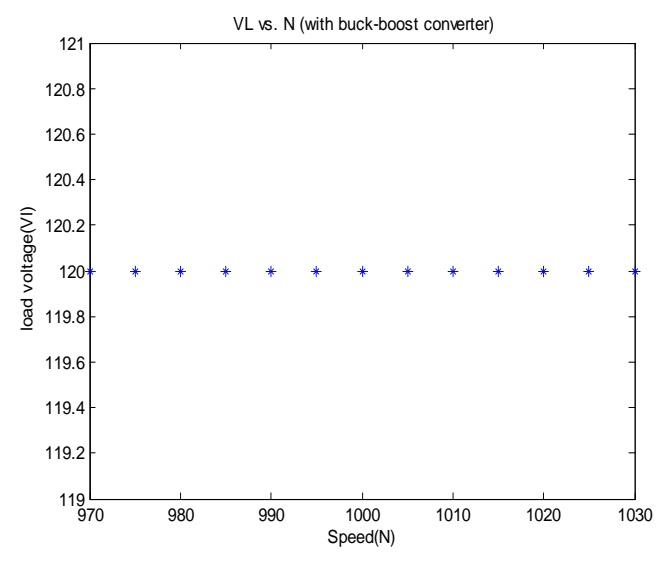

Fig-10: $\mathrm{V}_{\mathrm{L}}$ vs. N Curve (Buck-Boost)

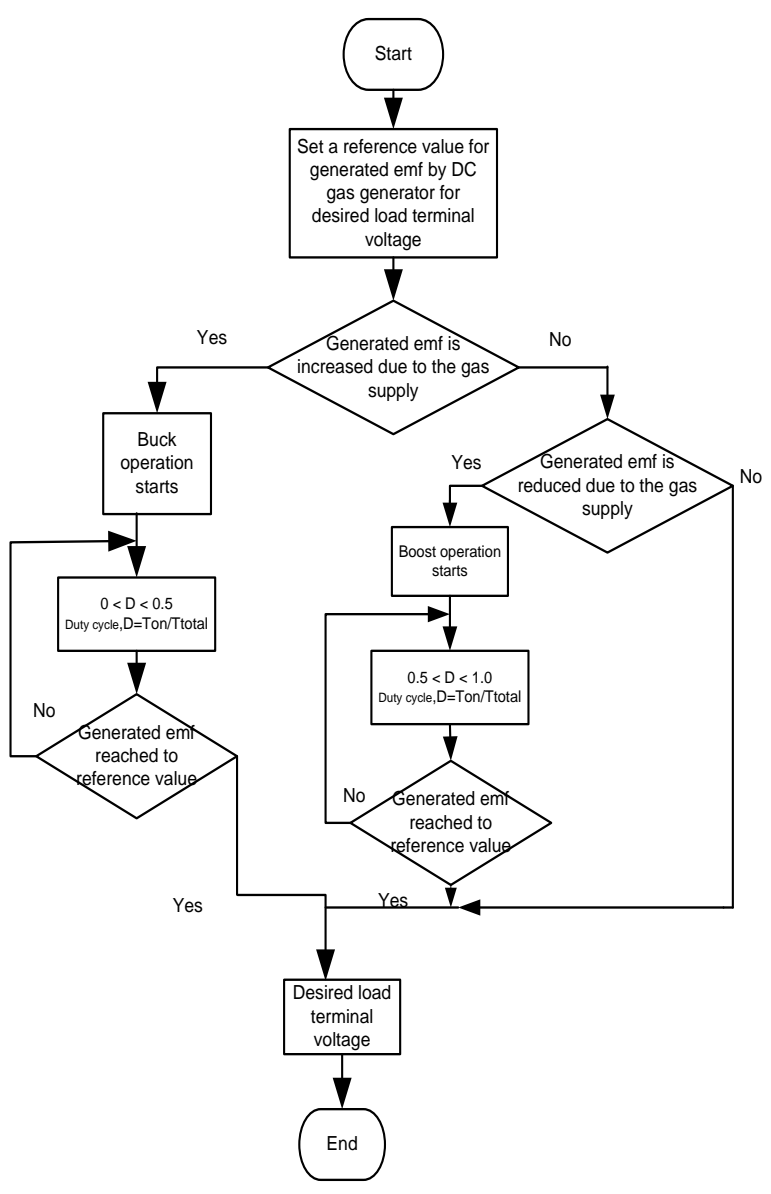

Fig-11: Algorithm for Buck-Boost controlled circuit

If the load voltage is increased or decreased from desired value, this control circuit will simultaneously reduced it or increased it by changing duty cycle to protect load from voltage fluctuations.

Duty cycle $=\frac{\text { Voutput }}{\text { Voutput+Vinput }}$

\subsection{Duty cycle}

A duty cycle is the percentage of one period in which a signal is active. A period is the time it takes for a signal to complete an on-and-off cycle.

\section{on time of the signal \\ $\mathrm{D}=\overline{\text { Total time period of the signal }}$ \\ $X 100 \%$}

\subsection{Overview of the whole system}

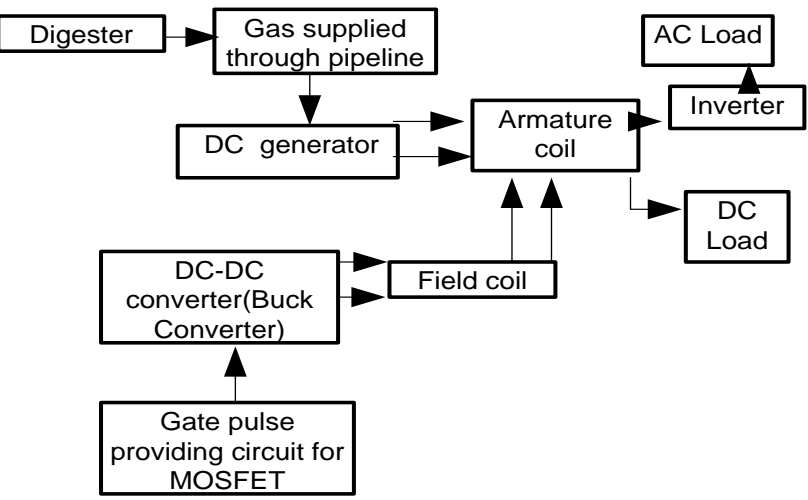

Fig-12: Overview of the whole System

\section{OBSERVATION:}

Table-6: Output of mathematical model and control circuits.

\begin{tabular}{|c|c|c|c|c|}
\hline \multicolumn{3}{|c|}{ Without converter } & \multicolumn{2}{|c|}{$\begin{array}{l}\text { Simulation is done } \\
\text { considering } 120 \text { volt } \\
\text { is the desired level of } \\
\text { terminal voltage of } \\
\text { the generator }\end{array}$} \\
\hline $\begin{array}{l}\text { Speed of } \\
\text { the prime } \\
\text { mover(N) } \\
\text { r.p.m }\end{array}$ & $\begin{array}{l}\text { Generated } \\
\text { emf }\left(E_{g}\right)\end{array}$ & $\begin{array}{l}\text { Terminal } \\
\text { voltage } \\
\left(\mathrm{V}_{\mathrm{L}}\right)\end{array}$ & $\begin{array}{l}\text { Terminal } \\
\text { voltage } \\
\left(\mathrm{V}_{\mathrm{L}}\right) \\
\text { With } \\
\text { Buck } \\
\text { converter }\end{array}$ & $\begin{array}{l}\text { Terminal } \\
\text { voltage } \\
\left(\mathrm{V}_{\mathrm{L}}\right) \\
\text { With } \\
\text { Buck- } \\
\text { Boost } \\
\text { converter }\end{array}$ \\
\hline 970 & 118.8244 & 41.4000 & 41.4 & 120 \\
\hline 975 & 120.0525 & 54.5000 & 54.5 & 120 \\
\hline 980 & 121.2870 & 67.6000 & 67 & 120 \\
\hline 985 & 122.5278 & 80.7000 & 80 & 120 \\
\hline 990 & 123.7749 & 93.8000 & 93 & 120 \\
\hline 995 & 125.0283 & 106.9000 & 106 & 120 \\
\hline 1000 & 126.2880 & 120.0000 & 120 & 120 \\
\hline 1005 & 127.5540 & 133.1000 & 120 & 120 \\
\hline 1010 & 128.8264 & 146.2000 & 120 & 120 \\
\hline 1015 & 130.1051 & 159.3000 & 120 & 120 \\
\hline 1020 & 131.3900 & 172.4000 & 120 & 120 \\
\hline 1025 & 132.6813 & 185.5000 & 120 & 120 \\
\hline 1030 & 133.9789 & 198.6000 & 120 & 120 \\
\hline
\end{tabular}




\section{CONCLUTION:}

Introducing biogas electrification technology could be beneficiary in many ways:

- Small and medium plants can meet up their own power requirement in rural areas.

- Large farms can supply electricity to the national grid to reduce the electricity based problems.

- Reduce the environment pollution regarding conventional fuel based electricity generation technology

- Reduce pressure on natural gas for electricity generation

- Microcontroller based control panel can be introduced for better performing power generation system

- Cuk DC-DC converter can be used for better control over terminal voltage.

\section{REFERENCES}

[1] Assignment Point. "Present State of Electricity in Bangladesh". Internet: http://www.assignmentpoint.com/science/eee/prese nt-state-of-electricity-in-bangladesh.html, June 29, 2011

[2] The Daily Star. "Bangladesh's gas reserve to last until 2031". Internet: http://www.thedailystar.net/backpage/gas-reservelast-until-2031-104479, June 29, 2015

[3] Bangladesh Power Development Board. Internet: http://www.bpdb.gov.bd/bpdb/index.php?option=c om_content $\&$ view $=$ article $\& i d=150 \&$ Itemid $=16$

[4] A.Jamil. "Biogas and Cattle Organs- An Alternative Significant Source of Energy for Sustainable Development in Rural Bangladesh." M.Sc. Thesis, Södertorns Högskola, Stockholm, Sweden, 2006-07

[5] Power Cell. Internet: http://www.powercell.gov.bd/index.php?page_id=2 67

[6] "Biogas project on biogas plant". Internet: http://www.slideshare.net/TulikaGhosh1/biogasplant-project-47375752, April24,2015.

[7] Krzysztof Ziemiński, Magdalena Frąc, "Methane fermentation process as anaerobic digestion of biomass: Transformations, stages and microorganisms", Journal of Biotechnology ,Vol. 11(18), pp. 4127-4139, 1 March, 2012 Available online at http://www.academicjournals.org/AJB DOI: 10.5897/AJBX11.054 ISSN 1684-5315 (C) 2012 Academic Journals

[8] Fatema Tania " Solid Waste Management of Dhaka City: A Socio-economic analysis", Banglavision, ISSN: 2079-567X, Vol. 13 ,No. 1, January 2014

[9] Salma A. Iqbal, Shahinur Rahaman, Abu Yousuf, "Present Scenario of Biogas Technology in Bangladesh-Prospects, Potentials and Barriers,"Proceedings of the 15th Annual paper Meet, "APM 2013”, At Dhaka,Bangladesh,Pages: $1-9$

\section{BIOGRAPHIES}

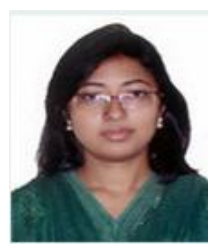

Sharmin Sobhan received the B.Sc. degree in Electrical and Electronics Engineering (EEE) from Ahsanullah University of Science and Technology (AUST), Dhaka, Bangladesh, in 2012.

She is currently doing M.Sc in EEE at Islamic University of Technology(IUT).Since 2012, she has been a lecturer of EEE dept. at AUST

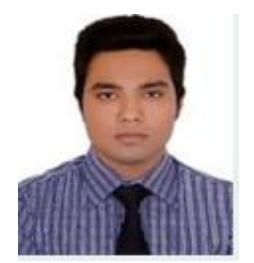

Tanvir Ahmad received the B.Sc. degree in Electrical and Electronics Engineering (EEE) from Ahsanullah University of Science and Technology (AUST), Dhaka, Bangladesh, in 2012.

$\mathrm{He}$ is currently doing M.Sc in EEE at Bangladesh University of Engineering and Technology (BUET).Since 2012, he has been a lecturer of EEE dept. at AUST. 